University of Montana

ScholarWorks at University of Montana

6-29-2007

\title{
Two modes of accelerated glacier sliding related to water
}

Joel T. Harper

University of Montana - Missoula, joel.harper@mso.umt.edu

Neil Humphrey

University of Wyoming

W. T. Pfeffer

University of Colorado Boulder

Brian Lazar

University of Colorado Boulder

Follow this and additional works at: https://scholarworks.umt.edu/geosci_pubs

Part of the Geology Commons

Let us know how access to this document benefits you.

\section{Recommended Citation}

Harper, J. T., N. F. Humphrey,W. T. Pfeffer, and B. Lazar (2007), Two modes of accelerated glacier sliding related to water, Geophys. Res. Lett., 34, L12503, doi:10.1029/2007GL030233.

This Article is brought to you for free and open access by the Geosciences at ScholarWorks at University of Montana. It has been accepted for inclusion in Geosciences Faculty Publications by an authorized administrator of ScholarWorks at University of Montana. For more information, please contact scholarworks@mso.umt.edu. 


\title{
Two modes of accelerated glacier sliding related to water
}

\author{
Joel T. Harper, ${ }^{1}$ Neil F. Humphrey, ${ }^{2}$ W. Tad Pfeffer, ${ }^{3}$ and Brian Lazar $^{3}$ \\ Received 31 March 2007; revised 5 May 2007; accepted 29 May 2007; published 29 June 2007.
}

[1] We present the first glacier-wide detailed measurement of basal effective pressure and related observations including bed separation to elucidate the role of water in sliding. The hard bedded glacier instrumented in our study exhibited two phases of accelerated sliding motion apparently driven by separate mechanisms. The first acceleration phase (up to 5 fold increase in speed) was closely tied to an increase in bed separation. The faster second phase (up to 9 fold increase in speed) was related to an unusually high level of connectivity of subglacial waters. We infer the first mode was related to cavity opening and the second mode was related to reduced ice contact with the bed. Glacier sliding over a hard bed is typically represented by sliding laws that include the effective basal pressure, but neither sliding phase was accompanied by a simultaneous decrease in local or regional effective pressure. Citation: Harper, J. T., N. F. Humphrey, W. T. Pfeffer, and B. Lazar (2007), Two modes of accelerated glacier sliding related to water, Geophys. Res. Lett., 34, L12503, doi:10.1029/2007GL030233.

\section{Introduction}

[2] Adjustments in the area and volume of glaciers and ice sheets are known to result from flow field changes as well as mass balance changes. Principal among flow changes are variations in basal sliding, which are implicated in recent changes in the velocity of Greenland outlet glaciers [Krabill et al., 1999; Thomas et al., 2000; Zwally et al., 2002]. Physical models typically treat effective pressure (the difference between ice overburden pressure and subglacial water pressure) as the dominant control of glacier sliding over bedrock [Fowler, 1987; Lliboutry, 1968; Röthlisberger, 1972]. Although increased sliding rates are typically assumed to be controlled by decreased effective pressure, the actual mechanism by which basal water controls sliding is poorly known and observations have thus far been inconsistent [Fountain and Walder, 1998]. In fact, no well-validated predictive sliding law exists with which to model this important phenomenon [Fountain and Walder, 1998; Hooke, 1998; Marshall et al., 2002].

[3] Glaciers commonly experience enhanced sliding during the spring melt season [Willis, 1995] implying that melt water input, or a significant change therein, leads to increased sliding. The magnitude of input often grows during summer, but enhanced sliding events are common

\footnotetext{
${ }^{1}$ Department of Geosciences, University of Montana, Missoula, Montana, USA.

${ }^{2}$ Department of Geology and Geophysics, University of Wyoming, Laramie, Wyoming, USA.

${ }^{3}$ Institute of Arctic and Alpine Research, University of Colorado, Boulder, Colorado, USA.

Copyright 2007 by the American Geophysical Union. 0094-8276/07/2007GL030233
}

in spring, so an initial rapid increase of water input appears to be more important to sliding than the actual quantity of water input [Fountain and Walder, 1998; Röthlisberger and Lang, 1987]. A common interpretation is that spring sliding results from pressure increases due to water input to a basal hydrological system incapable of efficiently draining the water.

[4] Between 2002 and 2006 we investigated the link between water and glacier sliding using Bench Glacier, Alaska (Figure 1) as a field laboratory. Our approach here is to test current theory with observations of hydrology and flow dynamics collected at local to glacier-wide length scales and second to year-long time scales.

\section{Instrumentation and Data}

[5] We installed 51 pressure transducers at Bench Glacier's bed and made a suite of ice velocity and hydrological measurements at locations spanning the distance between the glacier's terminus and headwall (Figure 1). Bed water pressure data were collected continuously from the subglacial sensor network for four and a half years and during five seasonal events of rapid sliding. Here we present data recorded over a 10-day period in 2003 that exhibit two distinct modes of rapid sliding. Observations from this period are remarkably similar to those from events in previous and subsequent years.

[6] Radar imaging indicates the glacier has a parabolic cross-section and does not have significant over-deepenings [Bradford and Harper, 2005]. The ice is temperate and the thickness is $150-210 \mathrm{~m}$ between the equilibrium line and near the terminus. We assume the bed is "hard" (i.e. little or no till) based on penetrometer tests, direct observations with cameras in 52 boreholes spaced along the glacier, and reflection amplitude analysis of over $10 \mathrm{~km}$ of radar imaging [Harper et al., 2005]. Thus, basal motion by till deformation appears unlikely.

[7] Surface velocities were measured at four locations with fixed differential GPS receivers, and at an additional 24 locations with an automated optical survey instrument (Figure 1). Propagation of errors used to estimate uncertainty of target velocities [Bevington and Robinson, 1992] suggests that targets within $300 \mathrm{~m}$ of the theodolite had a potential horizontal and vertical position error of $\pm 2.5 \mathrm{~mm}$, yielding a nominal surface velocity uncertainty of $\pm 6 \mathrm{~mm} \mathrm{~d}^{-1}$. At the centerline and midway along the glacier's length the minimum sustained velocity at GPS station G2 (Figure 1) was roughly $0.03 \mathrm{~m} \mathrm{~d}^{-1}$. This is the speed expected from ice deformation alone [Harper et al., 2001], and we assume that all multi-fold increases from this value were due to sliding, not deformation.

[8] Using measured displacements of the 24 stakes we computed surface velocities and strain rates in the longitudinal, transverse, and vertical directions within a $1.5 \times 10^{6} \mathrm{~m}^{2}$ 


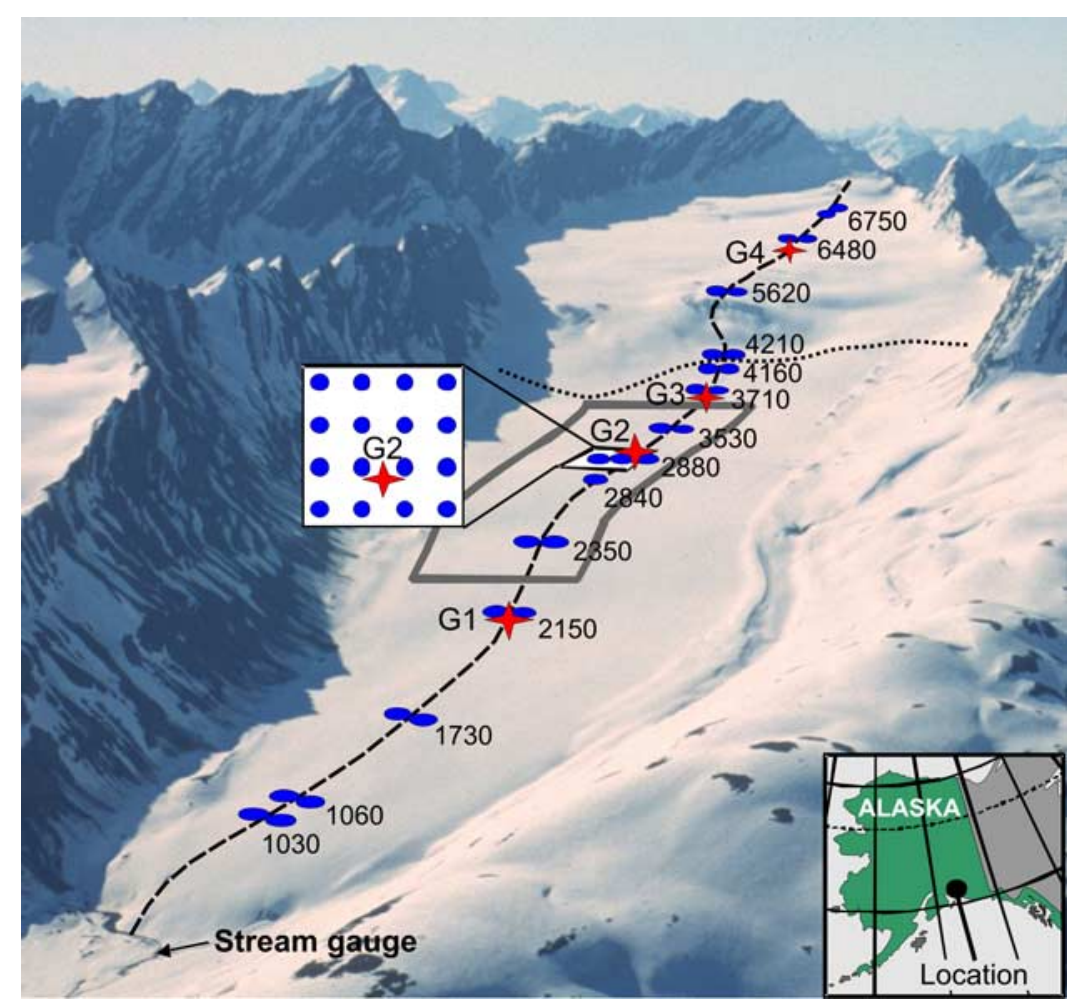

Figure 1. Photograph of Bench Glacier and measurement locations: ellipses are boreholes to the bed fitted with instrumentation; white box is borehole grid used in local effective pressure calculations; stars are GPS stations; gray rectangle is area of optical survey network. Numbers indicate meters from terminus; dashed line is approximately $7.2 \mathrm{~km}$. Dotted line is approximate position of equilibrium line.

region mid-way along the length of the ablation area [Lazar, 2004]. The difference between the measured surface vertical motion and the component calculated to result from ice deformation is ascribed to bed separation due to water infilling in basal cavities [Iken et al., 1983]. Following the method of Hooke et al. [1989] we calculated the bed separation $s$ with respect to time $t$

$$
\frac{d s}{d t}=-\left(u_{s} \tan \beta+\langle\dot{\varepsilon}\rangle H-\frac{d z}{d t}\right)
$$

where, $u_{s}$ is the horizontal sliding velocity, $\beta$ is bed inclination and $\mathrm{H}$ is ice thickness (both determined from radar and borehole drilling), $\langle\dot{\varepsilon}\rangle$ is the mean vertical strain rate, $z$ is surface elevation. By integrating the rate of change in cavity formation with respect to time, we obtain a time series of net bed separation which we assume to represent storage in cavities at the bed. Our measurements reflect a change in bed separation relative to conditions on the first day of the study interval, not the total amount of water stored.

[9] Water levels were measured at time intervals of 15 minutes in 2002, and at intervals that ranged from one second to five minutes in other years. Sensors at the base of boreholes measure subglacial water pressure by the common assumption that the borehole acts as a manometer. The overall error in the water heights between boreholes is up to $2 \mathrm{~m}$. The majority of this error results from surface melting, possibly leading to lowering of the cable into the hole (although steps were taken to fix the cables in place) and thus a less accurate estimate of the distance between the sensor and the bed. We averaged effective pressure over both local (10 s of meters) and regional (kilometers) length scales. The local effective pressure is represented as the average of 17 boreholes within a $100 \times 60 \mathrm{~m}$ area within the intensively surveyed region (Figure 1), and regional pressure was calculated from 29 boreholes spaced along the glacier.

\section{Results}

[10] Two rapid sliding phases occurred during the transition from winter (no surface melt water input) to summer (melt water input). Effective pressure during the spring speed up was low, but had been low for over six months since the previous autumn (Figure 2). During the speed up ( days 156-159; June 4-7) velocity increased from the winter deformation rate by up to five fold (Figure 3 ) with the sliding increase propagating as a wave moving up-glacier at approximately $145 \mathrm{~m} \mathrm{~d}^{-1}$. No sudden drop in effective pressure, locally or regionally averaged, accompanied the sudden increase in sliding motion. In fact, a small increase from previously low and sustained winter levels was observed during the passage of increased sliding. The first phase of rapid sliding did, however, correlate well with a substantial increase in bed separation (Figure 3).

[11] Following the first acceleration phase, velocity diminished to about twice the deformation rate for a period of two days. The slowing of the glacier accompanied a loss of all bed separation accumulated during the prior phase. 

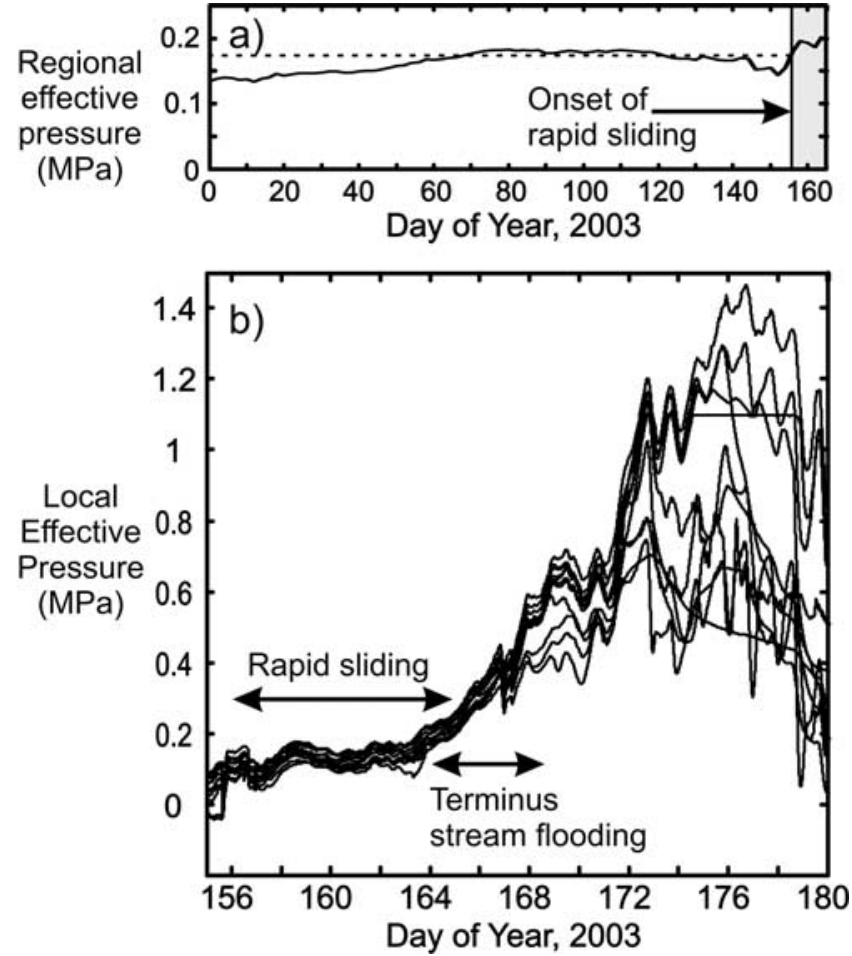

Figure 2. Water pressure during winter and late summer seasons: (a) pressure field during winter months averaged by 10 boreholes spanning $4 \mathrm{~km}$ and (b) 16 borehole grid (see Figure 1) demonstrated uniform pressure field during rapid sliding and large pressure gradients after sliding ended and terminus stream flooded.

During this interval we observed upwelling of basal waters (turbid and refreezing water) in boreholes using a submersible video camera, which was coincident with ice surface lowering [McGee et al., 2003]. We interpret the concurrent surface drop, loss of bed separation, and upwelling waters to all indicate collapsing of basal cavities.

[12] The velocity of individual locations increased to as much as nine times the deformation rate during the second acceleration phase ( days 161-165; June 9-13). This phase of rapid sliding also occurred with no decrease in effective pressure, but unlike the first phase there was no increase in bed separation. The pressure field during this period was unusually uniform and coherent with spatial coherency illustrated by numerous small $(1-2 \%)$ synchronous variations in the 16-hole grid (Figure 2). Termination of the second rapid sliding event coincided with glacierwide rising effective pressure and a five day period of flooding at the terminus outlet stream [Harper et al., 2005]. Temporary instrument failure during 2003 prevented GPS measurement of the velocity decline following the peak of the speed up; however other analyses suggest the speed-up event terminated abruptly on day 164.5-165.5 (June 13) [Harper et al., 2005]. The surface velocity associated with a similar two phase speed up was documented at Bench Glacier in 1999 and 2002 by other workers [Anderson et al., 2004; MacGregor et al., 2005] and by us in 2006, with each year having abrupt terminations of sliding and up to twelve days between the two phases.
[13] Actual water input to the bed could not be determined as it depends both upon inhomogeneous distribution of surface water and discrete englacial water routing. Light to moderate rain occurred on days 156-158 (June 4-6). Air temperature and solar radiation showed strong diurnal swings with generally increasing day-to-day trends through the two phases of rapid sliding. The first phase of sliding and separation increases was coincident with a rain event, while the second rapid sliding phase occurred during a time of steadily increasing solar and temperature driven melt.

[14] In neither sliding phase was the increasing speed accompanied by decreasing effective pressure as averaged either locally or regionally. During spring sliding events in other years we also found no direct correlation between effective pressure and velocity anywhere along the glacier. Effective pressures were low $(<0.5 \mathrm{MPa})$ starting in early winter when the sliding velocity was negligible. Effective pressure did rise substantially at the termination of the second phase, concurrent with volume loss from the bed implied by terminus stream flooding. Effective pressure then underwent large diurnal swings each year during late summer and reached values an order of magnitude greater

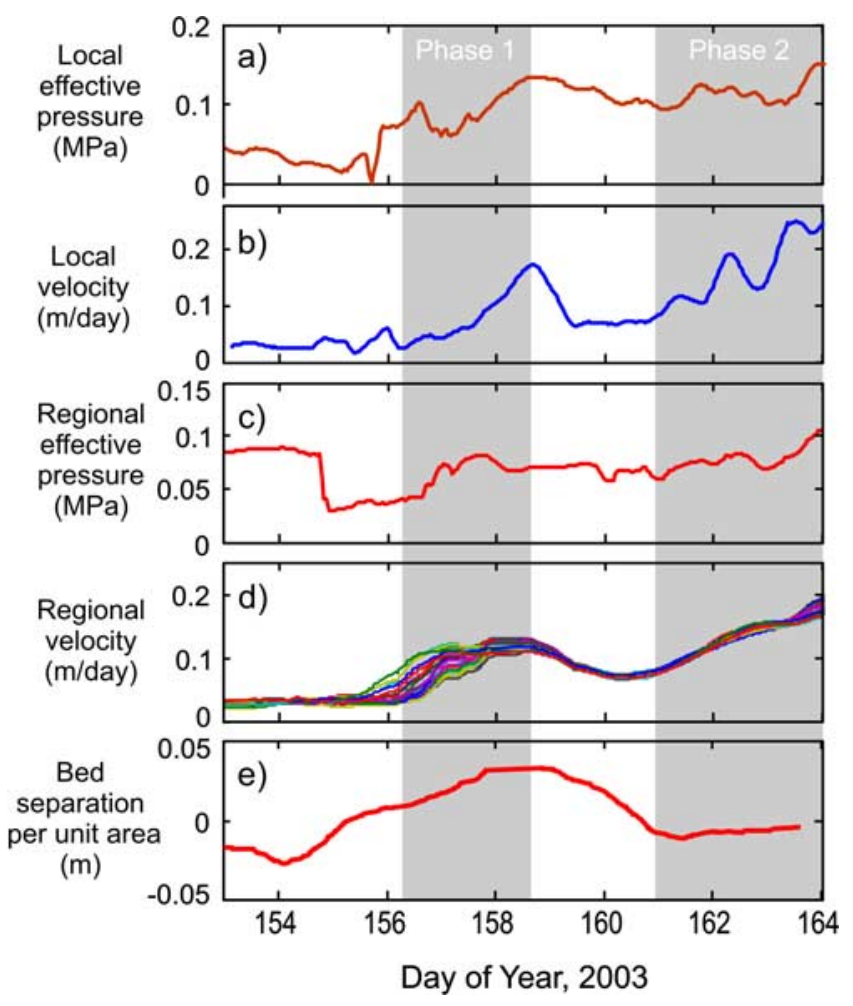

Figure 3. Time series comparing ice motion to effective pressure $\left(\mathrm{P}_{\text {eff }}\right)$ at the bed: (a) local effective pressure represented by average of 17 boreholes within $60 \mathrm{~m} \times$ 100 m; (b) GPS surface velocity of point G2 in Figure 1; (c) mean effective pressure at $\mathrm{km}$ scale represented by 29 boreholes; (d) regional velocity represented by 24 surveyed points within an area of $500 \mathrm{~m} \times 300 \mathrm{~m}$; and (e) bed separation calculated by equation (1) for a $1.5 \times 10^{6} \mathrm{~m}^{2}$ region mid-way along the ablation area (gray box in Figure 1). Shaded columns highlight timing of two phases of sliding accelerations. 


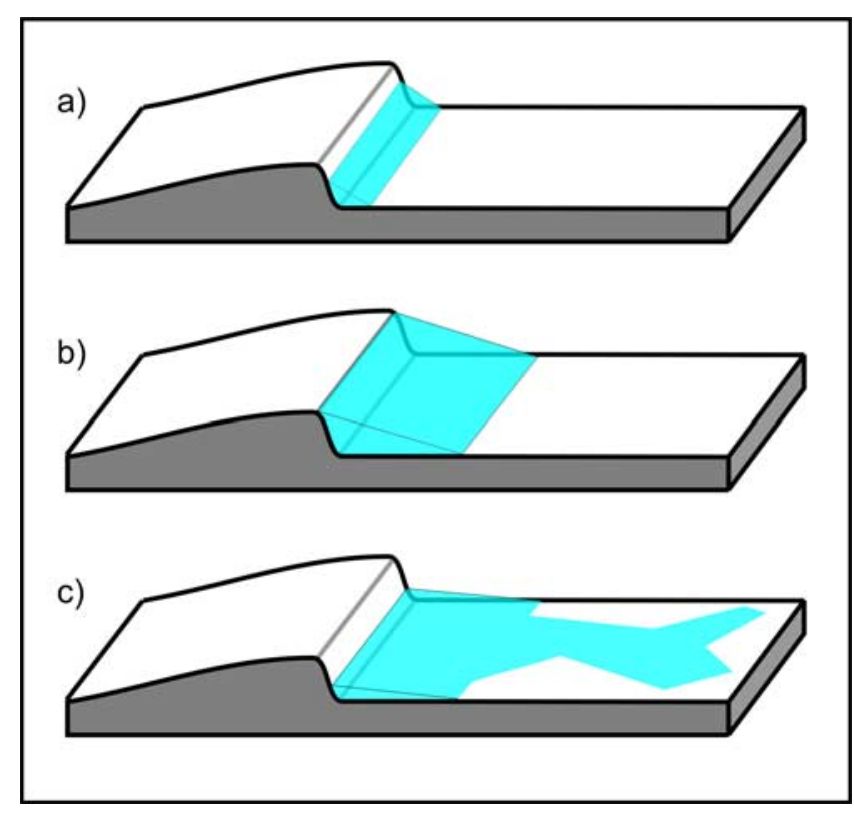

Figure 4. Conceptual model of the configuration of water before and during rapid sliding: (a) water occupies relatively small and isolated cavity spaces during winter; (b) the first mode of rapid sliding involves ice sliding up bedrock bumps thereby increasing storage in leeward cavities and opening some connections between cavities; and (c) the second mode of sliding occurs after cavity collapse and submergence of a large fraction of the bed.

than anytime during winter or the spring speed up [Fudge et al., 2005].

\section{Discussion and Conclusion}

[15] Multiple observational campaigns have detected strong correlations between subglacial water pressure and ice velocity [Iken and Bindschadler, 1986; Jansson, 1995; Sugiyama and Gudmundsson, 2004]. Yet other in-situ measurements have been unable to detect a functional relationship between the two variables [Hanson et al., 1998; Kamb et al., 1994; Vieli et al., 2004]. A common explanation is that sometimes bed measurements capture only locally anomalous pressure; by implication, a different length scale pressure is driving sliding. The data from Bench Glacier offer comparisons at multiple length scales, and are dense enough to consider observations over long space and time scales. These data do not necessarily contradict the hypothesis that low effective pressure is required for increased sliding rates, they simply fail to reveal any direct correlation between velocity increases and effective pressure decreases. Bench Glacier does show concurrent diurnal swings in water pressure (related to input) and doublings of velocity during mid-late summer [Fudge et al., 2005]. Similarly, other Alaskan glaciers have exhibited relatively slow sliding during times of high water input in late summer [Truffer et al., 2005].

[16] The initial wave of rapid sliding resulted in downglacier displacements of $0.3-0.5 \mathrm{~m}$ during each of the different study years. We hypothesize this displacement and the corresponding increase in bed separation represent ice sliding up the stoss side of bedrock bumps with cavities opening on the lee sides (Figure 4). The observed correlation between increased bed separation and velocity is predicted by accepted theory [Iken, 1981], although an expected concurrent decrease in effective pressure was lacking. Growth of cavities with constant low effective pressure has been suggested, however, based on theoretical arguments that consider a dynamic force balance between moving ice and the bed [Humphrey et al., 1987]. Borehole pressure records and artificially perturbed water levels (slug tests) during this period suggest basal water was contained in isolated and changing patches. We suspect the bed separation increase involved water entering scattered cavities with high bed separation and sufficient access to incoming water.

[17] Following the first phase of sliding, we theorize large cavities collapsed as water drained at a rate that exceeded water input. This resulted in surface lowering and a thin but widespread and more connected water network (Figure 4). Multiple lines of evidence suggest a greater fraction of the bed was covered by connected water during the second sliding phase than other times of the year: 1) borehole pressure records demonstrate complete synchronicity over 100's of meters (Figure 2), implying that all holes were connected by a highly transmissive water layer; 2) borehole slug tests show strong inter-hole connectivity and high transmissivity during this period [Shaha, 2004]; 3 ) outlet stream flooding at the culmination of the event [Harper et al., 2005] implies copious water at the bed. Sliding in this configuration was both rapid and sensitive to slight changes in input due to reduced contact between ice and bedrock and an effective means for distributing new water to further reducing basal drag. Increased sliding related to pressure changes in interconnected cavities has been suggested for other glaciers [Iken and Truffer, 1997] while here the water pressure was apparently relatively constant in the cavity network. The rapid sliding likely ended by the eventual development of channels which drained the bed [Kamb et al., 1985] and transferred load to more bedrock.

[18] Our glacier-wide measurements on a hard bedded glacier imply two separate modes of accelerated sliding during the annual spring increase of melt water flux to the bed. The first mode is associated with increasing bed separation, likely due to the opening of cavities in the lee of bedrock bumps. The second mode is associated with a highly connected subglacial water network that presumably submerges much of the bed and transfers load to a diminished area of ice in contact with the bed. While low effective pressure is perhaps a requisite condition, neither mode of sliding is directly related to declining values. The ice velocity and speed up duration of each mode is variable year-to-year. The ice displacement during the first mode, however, is theoretically limited by the geometry of bedrock bumps. The displacement during the second mode should only be limited by the development of an efficient conduit system and that drains the bed. These results reveal why sliding laws based primarily upon effective pressure often fail to be predictive, and lend insight for advancing our ability to evaluate the stability of glaciers resting on bedrock. 
[19] Acknowledgments. This work was supported by U.S. National Science Foundation, Office of Polar Programs, Arctic Natural Sciences.

\section{References}

Anderson, R. S., S. P. Anderson, K. R. MacGregor, E. D. Waddington, S. O'Neel, C. A. Riihimaki, and M. G. Loso (2004), Strong feedbacks between hydrology and sliding of a small alpine glacier, J. Geophys. Res., 109, F03005, doi:10.1029/2004JF000120.

Bevington, P. R., and D. K. Robinson (1992), Data Reduction and Error Analysis for the Physical Sciences, McGraw-Hill, New York.

Bradford, J. H., and J. T. Harper (2005), Wave field migration as a tool for estimating spatially continuous radar velocity and water content in glaciers, Geophys. Res. Lett., 32, L08502, doi:10.1029/2004GL021770.

Fountain, A. G., and J. S. Walder (1998), Water flow through temperate glaciers, Rev. Geophys., 36, 299-328.

Fowler, A. C. (1987), Sliding with cavity formation, J. Glaciol., 33, $255-$ 267.

Fudge, T. J., J. T. Harper, N. F. Humphrey, and W. T. Pfeffer (2005), Diurnal water-pressure fluctuations: Timing and pattern of termination below Bench Glacier, Alaska, USA, Ann. Glaciol., 40, 102-106.

Hanson, B., R. L. Hooke, and E. M. Grace (1998), Short-term velocity and water-pressure variations down-glacier from a riegel, Storglaciaren, Sweden, J. Glaciol., 44, 359-367.

Harper, J. T., N. F. Humphrey, W. T. Pfeffer, T. Fudge, and S. O'Neel (2005), Evolution of subglacial water pressure along a glacier's length, Ann. Glaciol., 40, 31-36.

Harper, J. T., N. F. Humphrey, W. T. Pfeffer, S. V. Huzurbazar, D. B. Bahr, and B. C. Welch (2001), Spatial variability in the flow of a valley glacier: Deformation of a large array of boreholes, J. Geophys. Res., 106, 85478562 .

Hooke, R. L. (1998), Principles of Glacier Mechanics, 248 pp., PrenticeHall, Upper Saddle River, N. J.

Hooke, R. L., P. Calla, P. Holmlund, M. Nilsson, and A. Stroeven (1989), A 3 year record of seasonal variations in surface velocity, Storglaciaren, Sweden, J. Glaciol., 35, 235-247.

Humphrey, N. F., E. D. Waddington, and J. S. Walder (1987), Coupling between water pressure and basal sliding in a linked-cavity hydraulic system, in The Physical Basis of Ice Sheet Modeling, IAHS Publ., 170, $105-119$.

Iken, A. (1981), The effect of the subglacial water pressure on the sliding velocity of a glacier in an idealized numerical model, J. Glaciol., 27, $407-421$.

Iken, A., and R. A. Bindschadler (1986), Combined measurements of subglacial water pressure and surface velocity of Findelengletscher, Switzerland: Conclusions about drainage system and sliding mechanism, J. Glaciol., 32, 101-119.

Iken, A., and M. Truffer (1997), The relationship between subglacial water pressure and velocity of Findelengletscher, Switzerland, during its advance and retreat, J. Glaciol., 43, 328-338.

Iken, A., H. Rothlisberger, A. Flotron, and W. Haeberli (1983), The uplift of Unteraargletscher at the beginning of the melt season-A consequence of water storage at the bed?, J. Glaciol., 29, 28-47.

Jansson, P. (1995), Water pressure and basal sliding on Storglaciaren, northern Sweden, J. Glaciol., 41, 232-240.
Kamb, B., et al. (1985), Glacier surge mechanism: 1982-1983 surge of Variegated Glacier, Alaska, Science, 277, 469-479.

Kamb, B., H. Engelhardt, M. A. Fahnestock, and N. Humphrey (1994), Mechanical and hydrological basis for rapid motion of a large tidewater glacier: 2. Interpretation, J. Geophys. Res., 99, 231-244.

Krabill, W., et al. (1999), Rapid thinning of parts of the southern Greenland Ice Sheet, Science, 283, 1522-1524.

Lazar, B. (2004), Relationship between water storage and sliding in a temperate valley glacier, M. S. thesis, 72 pp., Univ. of Colo., Boulder.

Lliboutry, L. (1968), General theory of subglacial cavitation and sliding of temperate glaciers, J. Glaciol., 7, 21-58.

MacGregor, K. R., C. A. Riihimaki, and R. S. Anderson (2005), Spatial and temporal evolution of rapid basal sliding on Bench Glacier, Alaska, USA, J. Glaciol., 51, 49-63.

Marshall, S. J., T. S. James, and G. K. C. Clarke (2002), North American Ice Sheet reconstructions at the Last Glacial Maximum, Quat. Sci. Rev., 21(1-3), 175-192.

McGee, B. W., J. T. Harper, N. F. Humphrey, and W. T. Pfeffer (2003), Water flow through widespread and interconnected void spaces at depth in a temperate glacier, Eos Trans. $A G U, 84(46)$, Abstract C11C-0850.

Röthlisberger, H. (1972), Water pressure in intra- and subglacial channels, J. Glaciol., 11, 177-203.

Röthlisberger, H., and H. Lang (1987), Glacial Hydrology, Glaciofluvial Sediment Transport, pp. 207-284, John Wiley, New York.

Shaha, J. M. (2004), Investigation of subglacial and englacial hydrology using borehole slug tests: Bench Glacier, Alaska, M. S. thesis, 154 pp., Univ. of Wyo., Laramie.

Sugiyama, S., and G. H. Gudmundsson (2004), Short-term variations in glacier flow controlled by subglacial water pressure at Lauteraargletscher, Bernese Alps, Switzerland, J. Glaciol., 50, 353-362.

Thomas, R. H., W. Abdalati, T. L. Akins, B. M. Csatho, E. B. Frederick, S. P. Gogineni, W. B. Krabill, S. S. Manizade, and E. J. Rignot (2000), Substantial thinning of a major east Greenland outlet glacier, Geophys. Res. Lett., 27(9), 1291-1294.

Truffer, M., W. D. Harrison, and R. S. March (2005), Record negative glacier balances and low velocities during the 2004 heat wave in Alaska, USA: Implications for the interpretation of observations by Zwally and others in Greenland, J. Glaciol., 51, 663-664.

Vieli, A., J. Jania, H. Blatter, and M. Funk (2004), Short-term velocity variations on Hansbreen, a tidewater glacier in Spitsbergen, J. Glaciol., 170, 389-398.

Willis, I. (1995), Intra-annual variations in glacier motion: A review, Progress Phys. Geogr., 19(1), 61-106.

Zwally, H. J., et al. (2002), Surface melt-induced acceleration of Greenland Ice-Sheet flow, Science, 297, 218-222.

J. T. Harper, Department of Geosciences, University of Montana, Missoula, MO 59812-1296, USA. (joel.harper@umontana.edu)

N. F. Humphrey, Department of Geology and Geophysics, University of Wyoming, Laramie, WY 82071, USA.

B. Lazar and W. T. Pfeffer, Institute of Arctic and Alpine Research, University of Colorado, Boulder, CO 80309-0450, USA. 